\title{
The Effect of pH on Soil Actinophage
}

\author{
By I. K. SYKES, S. LANNING AND S. T. WILLIAMS* \\ Botany Department, University of Liverpool, Liverpool L69 $3 B X$
}

(Received 28 April 1980; revised 5 September 1980)

\begin{abstract}
Actinophage active against both neutrophilic and acidophilic streptomycetes were isolated from a variety of soils by a specific enrichment method. No phage were detected in soils with a $\mathrm{pH}$ below $6 \cdot 0$, despite the presence of acidophilic streptomycetes in these soils. However, some phage isolated from neutral soils were able to lyse acidophilic streptomycetes at $\mathrm{pH} 5 \cdot 5$. Selected actinophage were shown to be stable between $\mathrm{pH} 5.5$ and 9.0 in sterile soils and broth, but were rapidly inactivated at lower or higher $\mathrm{pH}$ values. Survival of these phage was good in neutral soils, but negligible in acidic soils. This suggested that free phage were unable to remain infective in acidic soils, thus at least partially accounting for the failure to isolate them. Acidity was shown to have variable effects on several stages of phage replication including adsorption, penetration and the length of the latent period. The latter effect was directly related to the metabolic activity of the host.
\end{abstract}

\section{INTRODUCTION}

Acidity is an important factor governing the activity and survival of streptomycetes in soil. A survey of the $\mathrm{pH}$ requirements of streptomycetes isolated from two acid soils (Williams et al., 1971) revealed that most species could be categorized as neutrophiles or acidophiles. Neutrophilic species grew between $\mathrm{pH} 5.5$ and 8.5 with an optimum around $\mathrm{pH} 7.0$, whilst acidophiles grew between $\mathrm{pH} 3.5$ and 6.5 with optimum growth around $\mathrm{pH} 4.5$. Khan \& Williams (1975) demonstrated the presence of acidophilic actinomycetes in 17 acid soils; the majority of these were streptomycetes. It was concluded that acidophilic actinomycetes are widespread and may play important roles in acid soils. Studies on the effect of $\mathrm{pH}$ on growth rate and enzyme production in laboratory conditions further underlined the distinction between acidophilic and neutrophilic streptomycetes (Flowers \& Williams, 1977; Williams \& Flowers, 1978).

Phage can attack a wide range of hosts inhabiting diverse environments. Patel (1969) demonstrated the presence of phage of the thermophile Thermoactinomyces vulgaris in composts and showed it to be capable of survival and activity at elevated temperatures. Phage for Bacillus stearothermophilus (Saunders \& Campbell, 1966) and an extreme thermophile Thermus thermophilus (Sakaki \& Oshima, 1975) have also been reported. Phage capable of replication on salt-tolerant organisms and halophiles have also been detected (Zachary, 1974; Torsvik \& Dundas, 1974). However, acid-tolerant organisms, such as lactobacilli and lactic streptococci, are infected by phage, but always at $\mathrm{pH}$ values close to neutrality. The aim of this study was to determine if actinophage in soil are adapted to low $\mathrm{pH}$ as are some of their potential hosts.

\section{METHODS}

Soils. Details of soils screened for actinophage are given in Table 1. The constituent horizons of the two podzolic soils (Freshfield and Delamere) were analysed separately. The presence of actinomycetes had been demonstrated previously in all soils and studied in detail in the podzolic samples (Davies \& Williams, 1970; Khan 
$\&$ Williams, 1975) and in the salt lake soil (Taber, 1959). Soil samples were stored at $4{ }^{\circ} \mathrm{C}$ in polyethylene screw-cap bottles for up to $7 \mathrm{~d}$. with the exception of the salt lake soil, which was stored for 8 years. The $\mathrm{pH}$ of soil samples was determined with a glass electrode (Reed \& Cummins, 1945).

Streptomycetes. Five neutrophilic and three acidophilic streptomycetes were used for phage isolation. The neutrophilic isolates were A29 (from an arable soil, pH 7.2), F6, Fi3 (Davies \& Williams, 1970) and C5 (Watson \& Williams, 1974) (from Freshfield pine forest soil, C horizon, $\mathrm{pH} 7.8$ ) and M8 (Mayfield et al., 1972) (from a deciduous woodland soil, $\mathrm{pH} 6 \cdot 0$ ). The acidophilic isolates were $\mathrm{H} 1$ (from Freshfield pine forest soil, $\mathrm{F}_{2} / \mathrm{H}$ horizon, pH 3.9), SW53 (from coal mine waste, $\mathrm{pH} 3.9$ ) and SW72 (from coal mine waste, $\mathrm{pH} 4.5$ ) (Khan $\&$ Williams, 1975). Cultures were grown on oatmeal agar (Shirling \& Gottlieb, 1966) at $25^{\circ} \mathrm{C}$ for $14 \mathrm{~d}$. The medium was adjusted to $\mathrm{pH} 7.0$ for neutrophiles and $\mathrm{pH} 5.5$ for acidophiles. Spore suspensions were prepared by transferring surface growth into $10 \mathrm{ml}$ sterile $20 \%(\mathrm{v} / \mathrm{v})$ glycerol, agitating for $5 \mathrm{~min}$ and filtering through sterile cotton wool to remove mycelium.

Phage isolation and enumeration. The following specific enrichment method for phage isolation was used. Soil samples $(25 \mathrm{~g})$ were added to flasks containing $50 \mathrm{ml}$ nutrient broth (CM1, Oxoid), adjusted to $\mathrm{pH} 5.5$ for acidophiles or to $\mathrm{pH} 7.0$ for neutrophiles. Each flask was inoculated with a streptomycete spore suspension to give a final concentration of approximately $1 \times 10^{7}$ colony-forming units (c.f.u.) ml ${ }^{-1}$ and incubated for $16 \mathrm{~h}$ at $25^{\circ} \mathrm{C}$ on an orbital shaker operating at $200 \mathrm{rev} \cdot \mathrm{min}^{-1}$. The suspension was then centrifuged at $600 \mathrm{~g}$ for $15 \mathrm{~min}$, and the supernatant fluid was passed through $0.45 \mu \mathrm{m}$ pore size Millipore filters and assayed for phage by the double-layer method (Adams, 1959).

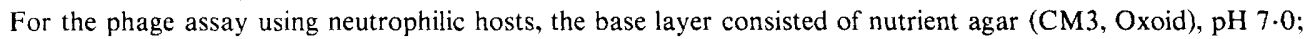
for acidophilic hosts, it consisted of glycerol/asparagine agar (Pridham \& Lyons, 1961), pH 5.5. Basal layers were dried at $65{ }^{\circ} \mathrm{C}$ for $20 \mathrm{~min}$ and air-cooled. The top layers consisted of nutrient broth or glycerol/asparagine broth with $0.8 \%(\mathrm{w} / \mathrm{v})$ agar (L13, Oxoid) seeded with the host spore suspension. Neutrophile assay plates were incubated for $16 \mathrm{~h}$ and acidophile assay plates for $48 \mathrm{~h}$, both at $25^{\circ} \mathrm{C}$.

Phage purification and storage. Single plaques were removed from the isolation plates with a Pasteur pipette, placed in $5 \mathrm{ml}$ nutrient broth and vigorously shaken for 1 to $2 \mathrm{~min}$. The extract was filter-sterilized and assayed for plaque-forming ability. This purification cycle was repeated twice before high titre stocks were prepared from single plaques.

Stock phage suspensions were prepared by inoculating nutrient agar base layers with $1 \mathrm{ml}$ purified phage [approximately $1 \times 10^{4}$ plaque-forming units (p.f.u.) $\mathrm{ml}^{-1}$, overlaying with $0.6 \%(\mathrm{w} / \mathrm{v})$ nutrient agar seeded with host spores and incubating at $25^{\circ} \mathrm{C}$ for $16 \mathrm{~h}$. The confluently lysed plates were flooded with $5 \mathrm{ml}$ nutrient broth and allowed to stand at room temperature for $2 \mathrm{~h}$. Lysates containing approximately $5 \times 10^{9} \mathrm{p} . f . \mathrm{u}$. $\mathrm{ml}^{-1}$ were collected, filtered and stored at $4^{\circ} \mathrm{C}$.

Phage morphologv. High titre suspensions of two phage ( $\mathrm{f} 6$ and $\mathrm{fl}$ ) in $0.1 \mathrm{M}$-ammonium acetate were stained with $2 \%(\mathrm{w} / \mathrm{v})$ phosphotungstic acid and examined with an electron microscope (Corinth 500, A.E.I.) at $60 \mathrm{kV}$.

Host-range. Phage isolated from soil were tested on a range of neutrophilic and acidophilic streptomycetes. Nutrient broth (CM1, Oxoid) containing $0.6 \%(\mathrm{w} / \mathrm{v})$ agar was seeded with a host spore suspension, poured over a nutrient agar base layer and allowed to solidify. The $\mathrm{pH}$ of the media in both layers was adjusted to $\mathrm{pH} 7.0$ for assay on neutrophiles and pH 5.5 for acidophiles. Spots of phage suspension in nutrient broth (appropriately diluted to yield single plaques) were inoculated on to the surface layer (eight phage isolates per plate) and plates were air-dried in a laminar flow cabinet. Neutrophile assay plates were incubated for $16 \mathrm{~h}$ at $25^{\circ} \mathrm{C}$ and acidophile assay plates for $48 \mathrm{~h}$ at $25^{\circ} \mathrm{C}$, before plaques were noted.

Effect of $\mathrm{pH}$ on stability of phage. Addition of phage $\mathrm{f} 6$ and $\mathrm{f} 13$ to a range of different buffers and media at $\mathrm{pH} 7.0$ for $1 \mathrm{~h}$ at $25^{\circ} \mathrm{C}$ showed that optimum survival (99 to $100 \%$ ) was obtained in glucose/Casamino acids/proline (G.C.P.) broth (Flowers \& Williams, 1977). This medium was therefore used to test the effect of $\mathrm{pH}$ on stability. Flasks containing $20 \mathrm{ml} \mathrm{G.C.P.} \mathrm{broth} \mathrm{were} \mathrm{adjusted} \mathrm{to} \mathrm{the} \mathrm{selected} \mathrm{pH} \mathrm{in} \mathrm{the} \mathrm{range} 4.0$ to 11.0 with $0.1 \mathrm{M}-\mathrm{HCl}$ or $0.1 \mathrm{M}-\mathrm{KOH}$ and allowed to equilibrate for $15 \mathrm{~min}$ at room temperature. The $\mathrm{pH}$ was readjusted if necessary. Phage suspension was added to each flask to give a final concentration of approximately $5 \times$ $10^{4}$ p.f.u. $\mathrm{ml}^{-1}$. Flasks were incubated at $25^{\circ} \mathrm{C}$ on an orbital shaker operating at $60 \mathrm{rev}$. $\mathrm{min}^{-1}$ for $24 \mathrm{~h}$. The $\mathrm{pH}$ of the suspension was checked before and after the experiment. Samples were withdrawn at intervals and assayed for phage by the double-layer method using nutrient agar basal and top layers at $\mathrm{pH} 7 \cdot 0$. Death rates were calculated from the slopes obtained by regression of $\log _{10}$ (surviving phage) against time for each $\mathrm{pH}$ value.

Soils (Table 1) were also used to determine the effect of $\mathrm{pH}$ on the stability of phage $\mathrm{f6}$ and f13. Soils were air-dried at room temperature for $96 \mathrm{~h}$ and homogenized to remove large aggregates. The moisture-holding capacity and $\mathrm{pH}$ of the dried soils were determined. Samples $(30 \mathrm{~g})$ of soil were placed in flasks and a phage suspension of known titre in nutrient broth, $\mathrm{pH} 7 \cdot 0$, was added to each flask to give a final moisture content of $75 \%$ moisture-holding capacity and a phage concentration of approximately $1 \times 10^{6}$ p.f.u. (g soil) $)^{-1}$. Immediately after the addition of phage $\left(t_{0}\right)$ and subsequently at $3 \mathrm{~min}$ and $200 \mathrm{~h}$, two $1 \mathrm{~g}$ samples were transferred to flasks containing $10 \mathrm{ml}$ nutrient broth, $\mathrm{pH} \mathrm{7.0.} \mathrm{These} \mathrm{were} \mathrm{placed} \mathrm{on} \mathrm{an} \mathrm{orbital} \mathrm{shaker} \mathrm{operating} \mathrm{at} 200 \mathrm{rev} . \mathrm{min}^{-1}$ for $30 \mathrm{~min}$. The $\mathrm{pH}$ of the extract was checked frequently and readjusted to neutrality with $0.1 \mathrm{M}-\mathrm{KOH}$ (especially with the acid soils). The extract was assayed for phage. 

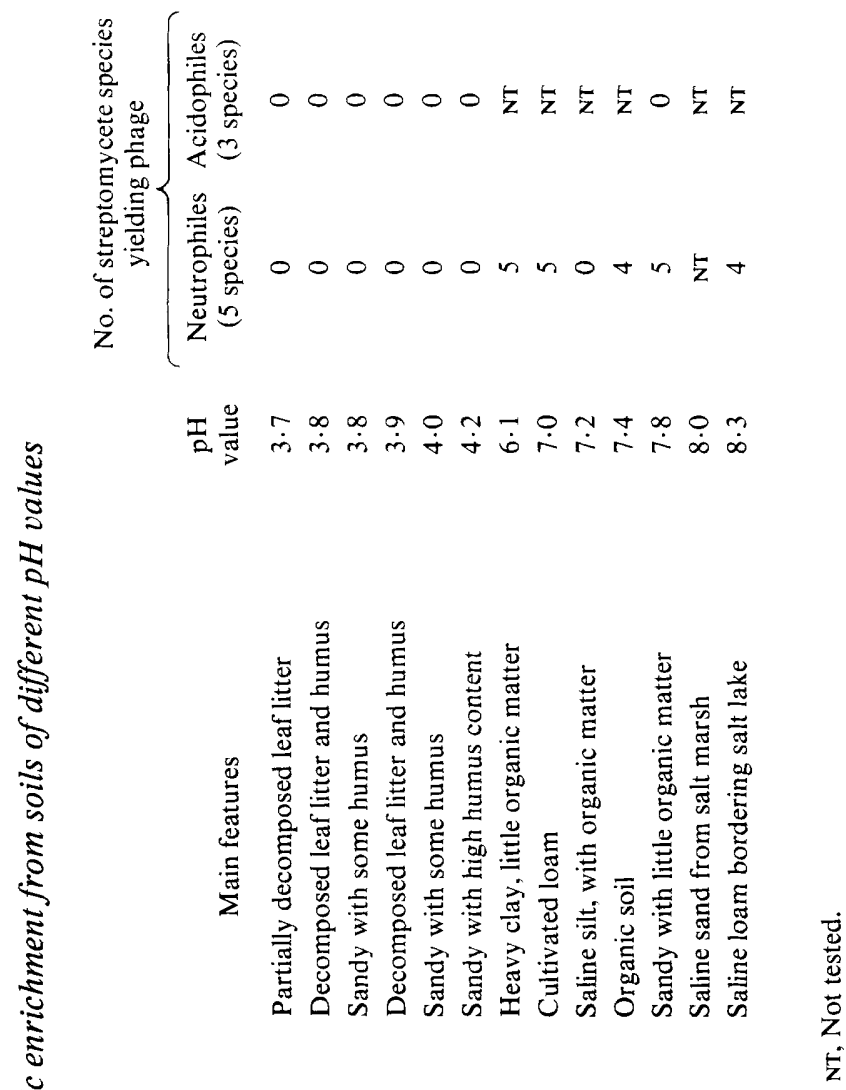

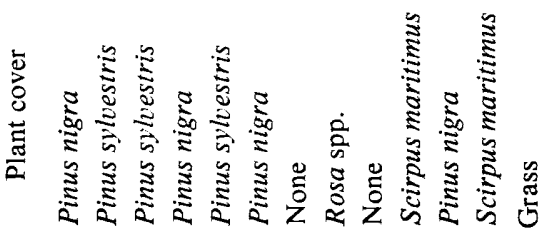
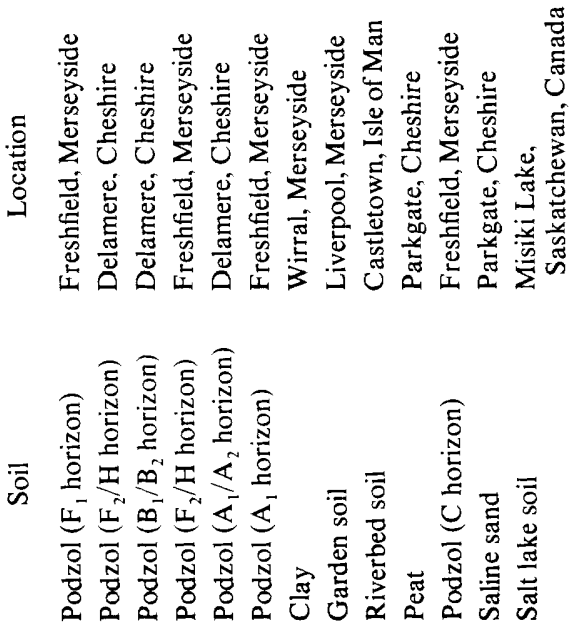
pH requirements of hosts used in adsorption and infectivity tests. Streptomycetes with different $\mathrm{pH}$ requirements for growth were selected (Table 2): F6 and F13 were the propagation hosts of phage f6 and f13, respectively. Host spore suspension $(0.5 \mathrm{ml})$ was added to flasks containing $35 \mathrm{ml}$ G.C.P. broth buffered to a range of $\mathrm{pH}$ values. The total number of spores in each flask was counted, using a Thoma counting slide, before incubation at $25^{\circ} \mathrm{C}$ on an orbital shaker operating at $100 \mathrm{rev} \cdot \mathrm{min}^{-1}$. When spores had germinated, $3 \mathrm{ml}$ host culture were transferred to a Clarke-type polarographic electrode (Rank Bros., Cambridge) and allowed to equilibrate for 5 min with constant agitation to ensure oxygen saturation. The electrode was sealed and the ambient temperature was maintained at $25^{\circ} \mathrm{C}$. The concentration of germinated spores in the electrode was calculated by comparing the percentage of spores germinated before and after testing. Respiration rates expressed as $\mathrm{mV}$ deflection per $10^{6}$ germinated spores $\min ^{-1}$ were plotted against $\mathrm{pH}$ values, and the $\mathrm{pH}$ optimum and range were calculated for each streptomycete (Table 2).

Effect of pH on adsorption of phage. Flasks containing $20 \mathrm{ml} \mathrm{G.C.P.} \mathrm{broth} \mathrm{were} \mathrm{adjusted} \mathrm{to} \mathrm{the} \mathrm{optimum} \mathrm{pH}$ for each of the four hosts, inoculated with spores to give a concentration of approximately $5 \times 10^{7} \mathrm{c} . f . u . \mathrm{ml}^{-1}$ and incubated at $25^{\circ} \mathrm{C}$. The number of germlings was determined using a Thoma counting slide. The suspensions were adjusted to the desired $\mathrm{pH}$ with $0.1 \mathrm{M}-\mathrm{HCl}$ or $0.1 \mathrm{M}-\mathrm{KOH}$ and phage were added $(0.01$ to 0.05 phage per germling). At intervals, $2 \mathrm{ml}$ of the suspension was removed, membrane-filtered and appropriately diluted. The filtrate was assayed for phage by the double-layer method using nutrient agar basal and top layers adjusted to pH 5.5 or $7 \cdot 0$, and incubated at $25^{\circ} \mathrm{C}$. The minimum possible pH for phage stability was 4.9 (f13) or 4.4 (f6). Ungerminated spores were also tested.

Adsorption was initially linear, as determined by measurement of percentage adsorption against time, and then it declined: $18 \mathrm{~min}$ was selected as a suitable period for adsorption for all host/phage combinations except $\mathrm{H} 1 / \mathrm{f} 13$, where $10 \mathrm{~min}$ was appropriate. Adsorption rates of those host/phage combinations shown to give lysis in host-range tests were studied at the selected period over a range of $\mathrm{pH}$ values. Adsorption was expressed as $K$, the adsorption velocity constant (Adams, 1959):

$$
K=\frac{2 \cdot 3}{B t} \times \log _{10}\left(\frac{P_{0}}{P_{\mathrm{t}}}\right)
$$

where $B$ is the bacterial concentration (c.f.u. $\mathrm{ml}^{-1}$ ), $P_{0}$ is the initial phage concentration (p.f.u. $\mathrm{ml}^{-1}$ ), $P_{\mathrm{t}}$ is the phage concentration at $t$ min (p.f.u. $\mathrm{ml}^{-1}$ ) and $t$ is the period of adsorption ( $18 \mathrm{~min}$, except $10 \mathrm{~min}$ for $\mathrm{H} 1 / \mathrm{f} 13$ ).

Effect of $\mathrm{pH}$ on overall replication. Flasks of G.C.P. broth buffered at different $\mathrm{pH}$ values were seeded with host spores to give a concentration of approximately $5 \times 10^{7}$ c.f.u. $\mathrm{ml}^{-1}$ and phage to give a concentration of 0.01

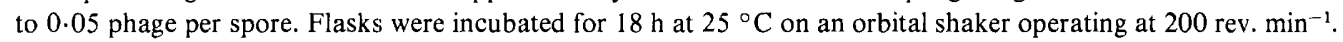
Evidence for replication was obtained from a comparison of p.f.u. at $t=0$ and $18 \mathrm{~h}$. Control flasks without host were set up at the lowest $\mathrm{pH}$ to check phage stability.

Efficiency of infection. Germling suspensions were taken at the end of the adsorption period (see above) and used to determine the number of phage adsorbed in the $\mathrm{pH}$ range 4.4 to 6.9 . The final adsorption suspensions were filtered (Millipore, pore size $0.45 \mu \mathrm{m}$ ) and 2 to $3 \mathrm{ml}$ fresh broth was passed through to remove free phage trapped on the filter. The filters (carrying adsorbed phage) were resuspended in $10 \mathrm{ml}$ broth, agitated for $30 \mathrm{~s}$ and assayed immediately at $\mathrm{pH} 5.5$ or 7.0 for infective centres. The percentage efficiency of infection was calculated as [ (no. of infected germlings)/(no. of adsorbed phage) $] \times 100$.

Effect of pH on intracellular development. One-step growth experiments were performed on each phage/host combination at the optimum and a sub-optimum pH of the host (Table 2). Flasks of G.C.P. broth were adjusted to the appropriate $\mathrm{pH}$ with $0.1 \mathrm{M}-\mathrm{HCl}$ or $0.1 \mathrm{M}-\mathrm{KOH}$. Host spores were added to give a concentration of approximately $5 \times 10^{7}$ c.f.u. $\mathrm{ml}^{-1}$ and flasks were incubated at $25^{\circ} \mathrm{C}$ on an orbital shaker operating at 200 rev. $\min ^{-1}$. After germination of spores, $\mathrm{KCN}$ was added to give a concentration of $10^{-4} \mathrm{M}$ and the $\mathrm{pH}$ was readjusted to the initial value. Phage were added to each flask to give a concentration of 0.01 to 0.05 phage per germling and adsorption was allowed to proceed for $15 \mathrm{~min}$. A $1 \mathrm{ml}$ sample of adsorption mixture was then removed, filtered as before and the filter was washed to remove free phage. The filter was resuspended in $50 \mathrm{ml}$ $\mathrm{KCN}$-free broth, a 10-fold dilution was prepared and both suspensions were incubated in a shaking water-bath at $25^{\circ} \mathrm{C}$. At intervals, $0.1 \mathrm{ml}$ samples were removed from each flask, diluted and assayed for plaque-forming ability. The time at which the filters were washed in $\mathrm{KCN}$-free broth was designated $t_{0}$.

\section{RESULTS \\ Phage morphology}

Both phage $\mathrm{f} 6$ and $\mathrm{f} 13$ had hexagonal heads $(50 \mathrm{~nm}$ diam.) with non-contractile tails (145 and $175 \mathrm{~nm}$ long, respectively); they could be placed in Group B of Bradley (1967). Phage f6 
Table 2. pH requirements of streptomycete hosts, determined by oxygen uptake

\begin{tabular}{|c|c|c|c|c|}
\hline Streptomyc & es sp. & $\begin{array}{l}\text { Optimum pH } \\
\text { for growth }\end{array}$ & $\begin{array}{c}\text { Selected } \\
\text { sub-optimum pH }\end{array}$ & $\begin{array}{c}\mathrm{pH} \\
\text { range }\end{array}$ \\
\hline Neutrophiles & $\begin{array}{l}\text { F6 } \\
\text { F13 }\end{array}$ & $\begin{array}{l}7 \cdot 5 \\
6 \cdot 6\end{array}$ & $\begin{array}{l}6 \cdot 4 \\
5 \cdot 6\end{array}$ & $\begin{array}{l}4 \cdot 8-9 \cdot 3 \\
5 \cdot 3-9 \cdot 5\end{array}$ \\
\hline Acidophiles & $\begin{array}{l}\mathrm{SW} 72 \\
\mathrm{H} 1\end{array}$ & $\begin{array}{l}5 \cdot 7 \\
5 \cdot 4\end{array}$ & $\begin{array}{l}7 \cdot 0 \\
6 \cdot 5\end{array}$ & $\begin{array}{l}4 \cdot 7-7 \cdot 6 \\
3 \cdot 5-7 \cdot 0\end{array}$ \\
\hline
\end{tabular}

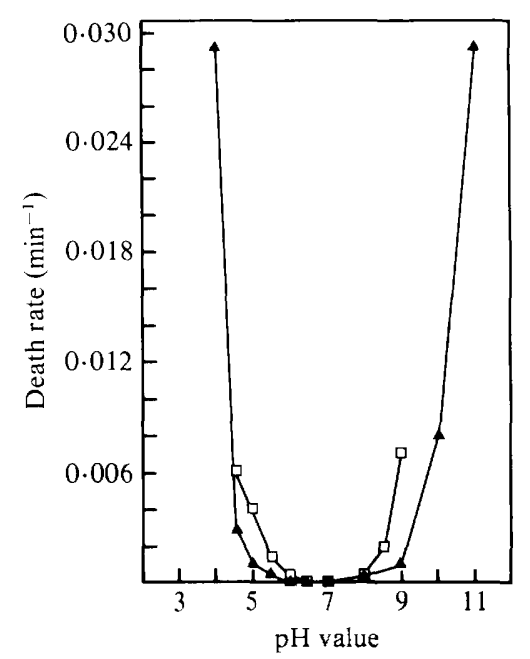

Fig. 1. Effect of pH value on death rates of phage f6 $(\mathbf{A})$ and phage f13 ( $\square)$ in G.C.P. broth. The death rate was calculated from the slope of the regression line of $\log _{10}$ (surviving phage) plotted against time.

formed large, clear plaques $(2.18 \mathrm{~mm}$ diam.) and $\mathrm{f} 13$ formed small, turbid plaques $(1.55 \mathrm{~mm}$ diam.).

\section{Distribution of phage}

Phage were not isolated from soils with a $\mathrm{pH}$ below $6 \cdot 1$ or from the riverbed soil (Table 1). It was not possible to isolate phage from soil by enrichment with acidophilic streptomycetes, even though the latter were known to be present in the acidic soils used (Khan \& Williams, 1975). Phage for the five neutrophilic hosts were isolated from soils of neutral $\mathrm{pH}$ values. All these phage were polyvalent, lysing more than one of the neutrophilic hosts tested. Acidophilic streptomycetes are not normally isolated from neutral soils and yet several of the phage isolated from such soils also lysed acidophilic hosts grown at $\mathrm{pH} 5 \cdot 5$. Thus phage host-ranges did not reflect the distribution of phage and hosts in the soils tested.

\section{Effect of $p H$ on stability of phage}

Inactivation of both phage $\mathrm{f} 6$ and $\mathrm{f} 13$ tested in broth followed simple first order kinetics, irrespective of the length of exposure to high or low $\mathrm{pH}$. Phage 6 showed maximum stability between pH 5.0 and 9.0, whereas f13 was most stable between pH 5.5 and 8.5 (Fig. 1).

Both phage $\mathrm{f} 6$ and $\mathrm{f} 13$ were unstable in soils with $\mathrm{pH} \leqslant 4 \cdot 2$, none being detected after only 3 min contact with such soils (Table 3 ). In soils with $\mathrm{pH} \geqslant 6 \cdot 1$, both phage f6 and f13 were detectable after $200 \mathrm{~h}$ although numbers declined over this period. 
Table 3. Survival of phage $f 6$ and 13 in soils of different $p H$ values

\begin{tabular}{|c|c|c|c|c|c|c|c|c|}
\hline \multirow[b]{2}{*}{ Soil } & \multirow{2}{*}{$\begin{array}{c}\mathrm{pH} \\
\text { value }\end{array}$} & \multirow[b]{2}{*}{ Time } & \multicolumn{3}{|c|}{ Phage f6 [p.f.u. (g dry wt soil) $\left.)^{-1}\right]$} & \multicolumn{3}{|c|}{ Phage f 13 [p.f.u. (g dry wt soil) ${ }^{-1}$ ] } \\
\hline & & & $\ldots$ & $3 \mathrm{~min}$ & $200 \mathrm{~h}$ & 0 & $3 \mathrm{~min}$ & $200 \mathrm{~h}$ \\
\hline Podzol $\left(F_{1}\right)$ & $3 \cdot 7$ & & $3 \times 10^{2}$ & 0 & 0 & 0 & 0 & 0 \\
\hline Podzol $\left(B_{1} / B_{2}\right)$ & $3 \cdot 8$ & & 0 & 0 & 0 & 0 & 0 & 0 \\
\hline Podzol $\left(\mathrm{F}_{2} / \mathrm{H}\right)$ & 3.9 & & $1 \times 10^{2}$ & 0 & 0 & 0 & 0 & 0 \\
\hline Podzol $\left(\mathrm{A}_{1} / \mathrm{A}_{2}\right)$ & $4 \cdot 0$ & & 0 & 0 & 0 & 0 & 0 & 0 \\
\hline Podzol $\left(A_{1}\right)$ & $4 \cdot 2$ & & $2 \times 10^{2}$ & 0 & 0 & $1 \times 10^{2}$ & 0 & 0 \\
\hline Clay & $6 \cdot 1$ & & $1 \times 10^{4}$ & NT & $2 \times 10^{3}$ & $3 \times 10^{3}$ & NT & $3 \times 10^{1}$ \\
\hline Garden soil & $7 \cdot 0$ & & $5 \times 10^{3}$ & NT & $4 \times 10^{2}$ & $2 \times 10^{3}$ & NT & $2 \times 10^{2}$ \\
\hline Peat & $7 \cdot 4$ & & $2 \times 10^{4}$ & NT & $2 \times 10^{4}$ & $2 \times 10^{3}$ & NT & $1 \times 10^{1}$ \\
\hline Podzol (C) & $7 \cdot 8$ & & $2 \times 10^{4}$ & NT & $3 \times 10^{3}$ & $5 \times 10^{4}$ & NT & $2 \times 10^{3}$ \\
\hline Salt lake soil & $8 \cdot 0$ & & $2 \times 10^{3}$ & NT & $3 \times 10^{4}$ & $6 \times 10^{4}$ & $\mathrm{NT}$ & $3 \times 10^{3}$ \\
\hline
\end{tabular}

NT, Not tested.

Table 4. Effect of $p H$ on phage adsorption

Adsorption rates were measured after $10 \mathrm{~min}$ for $\mathrm{Hl} / \mathrm{fl}$ and $18 \mathrm{~min}$ for all other host/phage combinations.

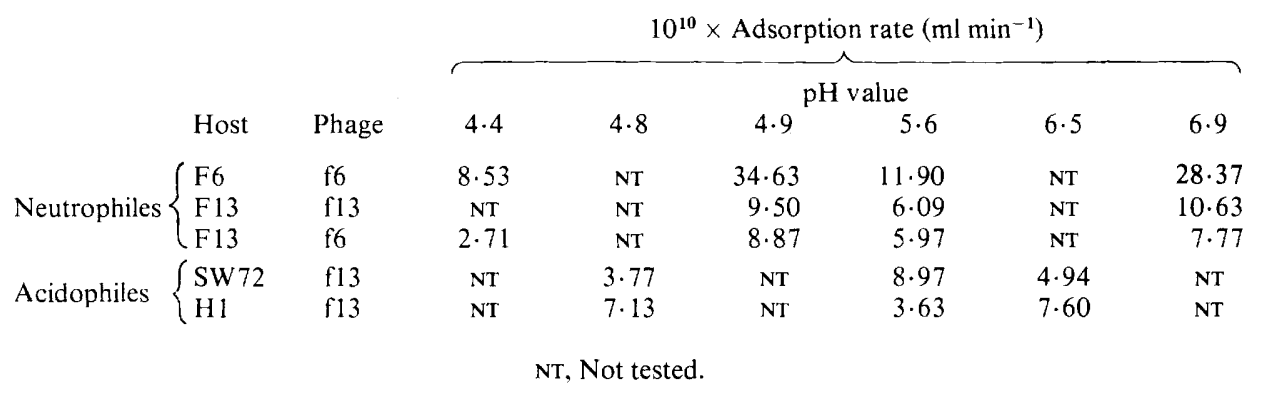

\section{pH requirements of hosts}

The four streptomycetes studied were active over different $\mathrm{pH}$ ranges and had different $\mathrm{pH}$ optima (Table 2). They were therefore suitable for the study of the phage cycle using hosts at optimum and sub-optimum $\mathrm{pH}$. They also allowed the study of the same phage on different hosts over a range of $\mathrm{pH}$ values.

\section{Effect of $p H$ on adsorption of phage}

Phage $\mathrm{f} 6$ adsorbed to both neutrophilic hosts (F6 and F13) throughout the $\mathrm{pH}$ range tested; adsorption to F6 was generally more efficient than to F13 (Table 4). Phage f13 adsorbed equally efficiently to neutrophilic (F13) and acidophilic (SW72 and H1) hosts at all $\mathrm{pH}$ values tested. No adsorption to ungerminated spores occurred.

\section{Effect of $p H$ on infectivity}

Overall replication. Acidity had little effect on the replication of phage $\mathrm{f} 13$ on all three hosts tested (F13, SW72 and H1) within the limits of stability of free phage. At low pH there was a decrease in the $18 \mathrm{~h}$ titres probably due to the inactivation of some free phage. Phage f6, however, failed to replicate on both $\mathrm{F} 6$ and $\mathrm{F} 13$ when the $\mathrm{pH}$ was below 6.0 for the $18 \mathrm{~h}$ period. This was despite the normal growth of the host and the stability of free phage at $\mathrm{pH}$ values lower than $6 \cdot 0$. 
Table 5. Effect of pH on phage infection

\begin{tabular}{|c|c|c|c|c|c|c|c|}
\hline & & & & Effici & f phage it & $(\%)$ & \\
\hline & Host & Phage & $4 \cdot 4$ & 4.9 & $\begin{array}{c}\mathrm{pH} \text { value } \\
5.6\end{array}$ & $6 \cdot 5$ & $6 \cdot 9$ \\
\hline & F6 & f6 & $8 \cdot 8$ & $14 \cdot 0$ & $13 \cdot 6$ & NT & $17 \cdot 4$ \\
\hline Neutrophiles & F13 & f 13 & NT & 4.4 & $6 \cdot 1$ & NT & $4 \cdot 4$ \\
\hline & F 13 & f6 & $51 \cdot 7$ & $41 \cdot 7$ & $61 \cdot 0$ & NT & $77 \cdot 2$ \\
\hline & SW72 & $\mathrm{f} 13$ & $4 \cdot 5$ & NT & $4 \cdot 1$ & $3 \cdot 7$ & NT \\
\hline Acidophiles & $\mathrm{H} 1$ & f13 & $2 \cdot 4$ & NT & $3 \cdot 2$ & $2 \cdot 6$ & NT \\
\hline
\end{tabular}

NT. Not tested.

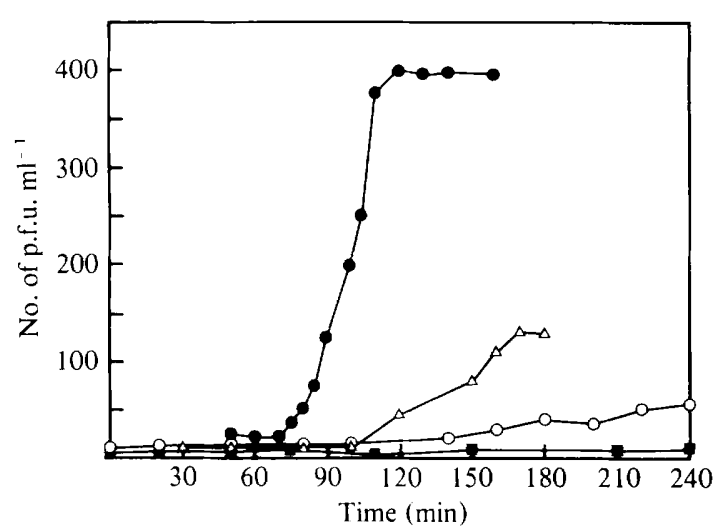

Fig. 2. One-step growth curves of phage $\mathrm{f} 6$ on streptomycete $\mathrm{F} 6$ under various $\mathrm{pH}$ regimes: $\mathrm{pH} 5 \cdot 6: 0, \mathrm{pH} \mathrm{7.0; \triangle}, \mathrm{pH} 5 \cdot 6$, adsorption at $\mathrm{pH} 7 \cdot 0 ; 0, \mathrm{pH} 7 \cdot 0$, adsorption at $\mathrm{pH} 5 \cdot 6$.

Efficiency of infection. Phage f13 showed a low percentage infection (2 to $6 \%$ ) on both neutrophilic and acidophilic hosts (Table 5). The efficiency of infection of F6 and F13 by phage f6 was considerably higher $(17.4$ and $77.2 \%$, respectively at $\mathrm{pH} 6.9)$. There was still a significant infection of both hosts below $\mathrm{pH} 6.0$ although this was reduced with decreasing $\mathrm{pH}$.

It was therefore necessary to try to account for the failure of phage f6 to replicate when kept below $\mathrm{pH} 6.0$ for $18 \mathrm{~h}$. Since phage f6 appeared to be capable of both adsorption and infection at low $\mathrm{pH}$, one-step growth experiments were performed under various $\mathrm{pH}$ regimes. When maintained at $\mathrm{pH} 7.0$ throughout the experiment, phage f6 replicated normally on $\mathrm{F} 6$ with a latent period of $73 \mathrm{~min}$ and a burst size of about 40 p.f.u. per infected cell (Fig. 2). When maintained at $\mathrm{pH} 5.6$, replication did not occur, thus confirming the previous observation of failure to replicate below $\mathrm{pH} 6 \cdot 0$. When phage $\mathrm{f} 6$ was allowed to adsorb for $15 \mathrm{~min}$ at $\mathrm{pH} 7 \cdot 0$, and then the $\mathrm{pH}$ was reduced to $5 \cdot 6$, replication occurred but the latent period was extended to $90 \mathrm{~min}$. When the phage were allowed to adsorb for $15 \mathrm{~min}$ at $\mathrm{pH} 5.6$ before increasing the $\mathrm{pH}$ to $7 \cdot 0$, there was little replication. Thus, it seems that phage $\mathrm{f} 6$ requires a $\mathrm{pH}$ above 6.0 for at least part of the infection period and possibly also for the early stages of replication.

\section{Effect of $\mathrm{pH}$ on intracellular replication}

The properties of the replication cycles of phage f6 and f13 determined at optimum and sub-optimum $\mathrm{pH}$ are summarized in Table 6. At sub-optimum $\mathrm{pH}$ the latent period was 
Table 6. Effect of $p H$ on intracellular replication of phage

\begin{tabular}{|c|c|c|c|c|c|c|}
\hline & Host & Phage & $\begin{array}{c}\mathrm{pH} \\
\text { value }\end{array}$ & $\begin{array}{l}\text { Latent period } \\
\qquad(\mathrm{min})\end{array}$ & $\begin{array}{l}\text { Burst size } \\
\text { (p.f.u. per cell) }\end{array}$ & $\begin{array}{l}\text { Rise period } \\
\quad(\min )\end{array}$ \\
\hline Neutrophiles & $\begin{array}{l}\text { F6 } \\
\text { F6 } \\
\text { F13 } \\
\text { F13 }\end{array}$ & $\begin{array}{l}\text { f6 } \\
\text { f6 } \\
\text { f13 } \\
\text { f13 }\end{array}$ & $\begin{array}{l}7 \cdot 5 \\
6 \cdot 4 \\
6 \cdot 6 \\
5 \cdot 6\end{array}$ & $\begin{array}{l}70 \\
80 \\
76 \\
95\end{array}$ & $\begin{array}{r}15.5 \\
35.8 \\
6.6 \\
9.6\end{array}$ & $\begin{array}{l}35 \\
10 \\
15 \\
40\end{array}$ \\
\hline Acidophiles & $\begin{array}{l}\text { SW72 } \\
\text { SW72 } \\
\text { H1 } \\
\text { H1 }\end{array}$ & $\begin{array}{l}\text { f13 } \\
\text { f13 } \\
\text { f13 } \\
\text { f13 }\end{array}$ & $\begin{array}{l}5.7 \\
7.0 \\
5.4 \\
6.4\end{array}$ & $\begin{array}{l}78 \\
90 \\
75 \\
86\end{array}$ & $\begin{array}{r}29 \cdot 1 \\
7.9 \\
11 \cdot 5 \\
11.0\end{array}$ & $\begin{array}{l}22 \\
19 \\
26 \\
28\end{array}$ \\
\hline
\end{tabular}

extended to varying degrees in all phage/host combinations. The largest burst sizes occurred under acidic conditions irrespective of the $\mathrm{pH}$ optimum of the host. The rise period of phage f13 grown on the acidophilic hosts (SW72 and H1) was not significantly different at either $\mathrm{pH}$.

\section{DISCUSSION}

The successful isolation of actinophage from soil appears to be largely dependent on soil $\mathrm{pH}$. No phage were isolated from soils with a $\mathrm{pH}$ below 6.1 despite the presence of potentially susceptible acidophilic hosts in these soils. Thus phage were abundant in the lower alkaline regions of the Freshfield podzol, but absent from the upper acidic layers (Table 1), although susceptible hosts were present throughout the profile (Davies \& Williams, 1970; Khan \& Williams, 1975). Williams \& Mayfield (1971) demonstrated the presence of neutrophilic streptomycetes in the acidic layers of Freshfield soil, but it was postulated that their activity was confined to microsites with a $\mathrm{pH}$ higher than that of the surrounding soil. Such microsites would be limited in space and time. If phage were able to replicate in them, they would be rapidly denatured when the $\mathrm{pH}$ returned to the ambient level.

The stability of phage $\mathrm{f} 6$ and $\mathrm{f} 13$ in broth was maximum in the $\mathrm{pH}$ range $5 \cdot 5$ to $9 \cdot 0$. The rapid transition towards instability over a small $\mathrm{pH}$ range $(0.5$ units) is characteristic of the acid denaturation of protein. Similar results have been obtained with various animal, plant and bacterial viruses (Finkelstein et al., 1940; Miller, 1944; Best \& Samuel, 1936; Putnam et al., 1949; Riverin et al., 1970). The survival of actinophage in soils of near-neutral pH was good, although some inactivation occurred over a $200 \mathrm{~h}$ period. Inactivation in soil occurred at faster rates than those obtained in G.C.P. broth, suggesting that other factors in the soil promoted phage inactivation. It has been shown that the $\mathrm{pH}$ stabilities of free phage differ from those adsorbed to clay (Sykes \& Williams, 1978). In acid soils ( $\mathrm{pH}<6.0$ ) phage survival was negligible. Thus the reactions of these phage to $\mathrm{pH}$ in both broth and soil indicate that free phage are not likely to be present in acidic soils.

Since acid-tolerant actinophage were not detected in acid soils it seems unlikely that acidophilic streptomycetes are attacked by phage in vivo. However, some phage isolated from neutral soils (f13 and a29) were capable of replicating on acidophilic hosts at pH 5.5. This suggests that the absence of phage activity in vivo is due to the instability of free phage at low $\mathrm{pH}$ rather than to host immunity.

The investigation of the effect of different factors on phage replication usually necessitates subjecting the host to the same factors. Consequently the results apply to a host/phage system in which the host has been altered. Effects on the phage replication cycle can then usually be explained in terms of host reaction. The use of phage capable of attacking both acidophiles and neutrophiles facilitated the study of the effect of $\mathrm{pH}$ on phage replication without subjecting the host to $\mathrm{pH}$ stress. 
Adsorption of phage f6 by neutrophilic hosts and $\mathrm{f} 13$ by neutrophilic and acidophilic hosts proceeded initially at a constant rate, after which rates declined. Adsorption rates were similar to those determined for other host/phage systems under optimum conditions.

$\mathrm{pH}$ has been shown to influence the adsorption of phage attacking a variety of hosts including Escherichia coli (Tolmach \& Puck, 1952; Puck \& Tolmach, 1954), Acholeplasma laidlawii (Fraser \& Fleischmann, 1974) and certain Salmonella species (Kwiatkowski \& Taylor, 1970; Takeda \& Uetake, 1973). The adsorption of phage f13 to all hosts appeared to be virtually independent of $\mathrm{pH}$. At low $\mathrm{pH}$ the attachment of phage $\mathrm{f} 13$ to acidophilic and neutrophilic hosts was equally efficient, indicating that adsorption was independent of the $\mathrm{pH}$ requirements of the host and therefore probably a passive process. Thompson \& Shafia (1962) suggested that the adsorption of phage $\phi / 4$ to Pseudomonas aeruginosa was an active process which could be totally prevented by the addition of inhibitors such as 2,4 dinitrophenol or cyanide. Some authors recognize the specific adsorption of phage by spores (Mikhailova, 1964; Wilde, 1966). In this study, phage were not adsorbed by ungerminated spores which agrees with the observations of Rice et al. (1954) and Dowding (1972), and suggests that since spore and mycelium walls are almost identical in composition, adsorption must be a highly specific process.

Phage f13 replicated normally on both acidophilic and neutrophilic hosts within the limits of its stability. Furthermore, the titres achieved at optimum host $\mathrm{pH}$ were similar for both acidophilic and neutrophilic hosts. In contrast, phage f6 did not replicate on either neutrophilic host if the media were maintained below $\mathrm{pH} 6 \cdot 0$, although it can survive at $\mathrm{pH} 5$ to 6 (Fig. 1). The step susceptible to low $\mathrm{pH}$ occurs during the infection period or the early stages of replication. If the $\mathrm{pH}$ is sufficiently high $(>6.0)$ during the infection period, replication will occur at a lower $\mathrm{pH}$ (Fig. 2). Since attachment itself was not $\mathrm{pH}$-dependent, low $\mathrm{pH}$ during the adsorption period may prevent infection or 'effective adsorption'. The low infection efficiency (Table 5) compared with adsorption suggests that a large proportion of phage $\mathrm{f} 6$ were ineffectively adsorbed.

The length of the latent period in the phage/host systems studied related to the metabolism of the host. For example, the latent period of phage f13 was similar on both neutrophilic and acidophilic hosts at their optimum $\mathrm{pH}$. The increase in the length of the latent period at sub-optimum $\mathrm{pH}$ is due to the reduced metabolic activity of the host. The rise period of phage $\mathrm{f} 13$ on neutrophilic and acidophilic hosts was independent of $\mathrm{pH}$ and no consistent effects were observed. The burst sizes of phage $\mathrm{f} 6$ and $\mathrm{f} 13$ were variable and independent of $\mathrm{pH}$. In general, burst sizes were lower than those previously reported for actinophage. Calberg-Bacq (1963) found that phage $\phi 17$ had a burst size of 120 , whereas Wilde (1966) reported it to be 2000. However, many factors can influence burst size, including the filamentous nature of the host, clumping and host age (Jones \& Bradley, 1965).

Thus, intracellular development is the stage of the phage cycle least influenced by $\mathrm{pH}$. The ability of phage to replicate equally well in several hosts with different $\mathrm{pH}$ optima would increase their chances of survival in the soil.

A research grant from N.E.R.C. is gratefully acknowledged.

\section{REFERENCES}

AdAms, M. (1959). Bacteriophages. New York: Wiley Interscience.

Best, R. J. \& Samuel, G. (1936). The reaction of the viruses of tomato spotted wilt and tobacco mosaic to the $\mathrm{pH}$ value of media containing them. Annals of Applied Biology 23, 509-537.

BRADLEY, D. E. (1967). Ultrastructure of bacteriophages and bacteriocins. Bacteriological Reviews 31. $230-314$.
Calberg-BACQ, C. M. (1963). Caracterisation d'une particule virale: l'actinophage $\phi 17$. Thèse de Doctorat en Sciences, Université de Liège, Belgium.

Davies, F. L. \& Williams, S. T. (1970). Studies on the ecology of actinomycetes in soil. I. The occurrence and distribution of actinomycetes in a pine forest soil. Soil Biology and Biochemistry 2. $227-238$. 
DowDING, J. E. (1972). Studies on bacteriophage of Streptomyces coelicolor. Ph.D. thesis, University of East Anglia, Norwich.

Finkelstein, H., MarX, W., Beard, D. \& Beard, J. W. (1940). pH stability of equine encephalomyelitis virus (Eastern strain) under various conditions. Journal of Infectious Diseases 66, 117-126.

Flowers, T. H. \& Williams, S. T. (1977). The influence of $\mathrm{pH}$ on the growth rate and viability of neutrophilic and acidophilic streptomycetes. Microbios 18, 223-228.

Fraser, D. \& FleischmanN, C. (1974). Interaction of mycoplasma with viruses. I. Primary adsorption of virus is ionic in mechanism. Journal of Virology 13, 1067-1074.

Jones, L. A. \& Bradley, S. G. (1965). The life-cycle of an actinophage for Streptomyces venezuelae. Journal of General Microbiology 40, 191-198.

Khan, M. R. \& Williams, S. T. (1975). Studies on the ecology of actinomycetes in soil. VIII. Distribution and characteristics of acidophilic actinomycetes. Soil Biology and Biochemistry 7, 345-348.

KwiatkowsKI, B. \& TAYlor, A. (1970). Two-step attachment of Vi phage $I$ to the bacterial surface. Acta microbiologica polonica 2, 13-20.

Mayfield, C. I., Williams, S. T., Ruddick, S. M. \& HATFIELD, H. L. (1972). Studies on the ecology of actinomycetes in soil. IV. Observations on the form and growth of streptomycetes in soil. Soil Biology and Biochemistry 4, 79-91.

Mikhailova, G. R. (1964). Cytological study of the development of Actinomyces aureofaciens infected with actinophage on agarized medium. Antibiotiki 3, 217.

Miller, G. M. (1944). Influence of $\mathrm{pH}$ and of certain other conditions on the stability of the infectivity and red cell agglutinating activity of influenza virus. Journal of Experimental Medicine 80, 507-520.

PAtel, J. J. (1969). Phages of lysogenic Thermoactinomyces vulgaris. Archiv für Mikrobiologie 69 , 294-300.

Pridham, T. G. \& Lyons, A. J. (1961). Streptomyces albus (Rossie-Doria) Waksman et Henrici: taxonomic study of strains labelled Streptomyces albus. Journal of Bacteriology 81, 431-441.

Puck, T. T. \& Tolmach, L. J. (1954). The mechanism of virus attachment to host cells. IV. Physicochemical studies on virus and cell surface groups. Archives of Biochemistry 51, 229-245.

Putnam, F. W., Kozloff, L. M. \& Neil, J. C. (1949). Biochemical studies of virus reproduction. I. Purification and properties of Escherichia coli bacteriophage T6. Journal of Biological Chemistry 179, 303-323.

ReEd, J. F. \& Cummins, R. W. (1945). Soil reactionglass electrode and colorimetric methods for determining $\mathrm{pH}$ values of soils. Soil Science 59, 97-104.

Rice, M. M., McCoy, E. \& KNIGHT, S. G. (1954). Bacteriophagy of Streptomyces griseus as revealed by phase microscope. Proceedings of the Society for Experimental Biology and Medicine 86, 344-345.
Riverin, S., Beaudoin, J. \& Vezina, C. (1970). Characterization of a nocardiophage for Nocardia restrictus. Journal of General Virology 6, 395407.

SAKAKI, Y. \& Oshima, T. (1975). Isolation and characterization of a bacteriophage infectious to an extreme thermophile, Thermus thermophilus HB8. Journal of Virology 15, 1449-1453.

Saunders, G. F. \& Campbell, L. L. (1966). Characterization of a thermophilic bacteriophage for Bacillus stearothermophilus. Journal of Bacterio$\log y$ 91, 340-348.

Shirling, E. B. \& Gottlieb, D. (1966). Methods for the characterization of Streptomyces species. International Journal of Systematic Bacteriology 16, 313-340.

SyKES, I. K. \& Williams, S. T. (1978). Interactions of actinophage and clays. Journal of General Microbiology 108, 97-102.

TABER, W. A. (1959). Identification of an alkalinedependent Streptomyces as Streptomyces caeruleus Baldacci and characterization of the species under controlled conditions. Canadian Journal of Microbiology 5, 335-344.

TAKEDA, K. \& UETAKE, H. (1973). In vitro interaction between phage and receptor lipopolysaccharide: a novel glycosidase associated with Salmonella phage $\mathrm{E}^{151}$. Virology 52, 148159.

Thompson, T. L. \& Shafia, F. (1962). Energy requirement for adsorption of bacteriophage $\phi \mathrm{U}^{-4}{ }^{\prime}$. Biochemical and Biophysical Research Communications 8, 467-470.

Tolmach, L. J. \& Puck, T. T. (1952). Mechanisms of virus attachment to host cells. Journal of the American Chemical Society 74, 551-553.

ToRsvik, T. \& DundAs, I. D. (1974). Bacteriophage of Halobacterium salinarium. Nature, London 248, 680-681.

Watson, E. T. \& Williams, S. T. (1974). Studies on the ecology of actinomycetes in soil. VII. Actinomycetes in a coastal sand belt. Soil Biology and Biochemistry 6, 43-52.

WILDE, P. (1966). Zur Vermehrung von Actinophagen. Archiv für Mikrobiologie 56, 120-132.

Williams, S. T. \& Flowers, T. H. (1978). The influence of $\mathrm{pH}$ on starch hydrolysis by neutrophilic and acidophilic streptomycetes. Microbios 20, 99106.

Williams, S. T. \& Mayfield, C. I. (1971). Studies on the ecology of actinomycetes in soil. III. The behaviour of neutrophilic streptomycetes in acid soil. Soil Biology and Biochemistry 3, 197-208.

Williams, S. T., Davies, F. L., Mayfield, C. \& KHAN, M. R. (1971). Studies on the ecology of actinomycetes in soil. II. The $\mathrm{pH}$ requirements of streptomycetes from two acid soils. Soil Biology and Biochemistry 3, 187-195.

ZACHARY, A. (1974). Isolation of bacteriophages to the marine bacterium Beneckea natriegens from coastal salt marshes. Applied Microbiology 27, 980-982. 